\title{
MISCELLANEA
}

\author{
GRAŻYNA RYBA
}

\section{INTERPRETACJA JAKO INSPIRACJA? DEKORACJA DRZWI DO KRUCHTY KATEDRY POZNAŃSKIEJ}

Zwiedzający katedrę św. św. Piotra i Pawła w Poznaniu, przesuwając się wzdłuż nawy południowej, mijają obojętnie wciśnięte w ciasną wnękę i ukryte $w$ cieniu bogato dekorowane metalowe drzwi prowadzace do kruchty. Także ci nieliczni, którzy pomijając główny portal w elewacji zachodniej decydują się wkroczyć do świątyni bocznym wejściem, szybko przechodzą przez pomieszczenie przedsionka, pospiesznie mijając metalowe drzwi wahadłowe wykonane przez Ireneusza Daczkę i Bogdana Fijałkowskiego w 1972 roku (il. 1). Nie poświęcają im większej uwagi i najczęściej nie podnoszą wzroku, aby dostrzec płaskorzeźbę usytuowaną powyżej, związaną z dekoracją drzwi zarówno pod względem formy, jak i treści, a stworzoną równolegle przez tych samych artystów.

Tymczasem obie realizacje zasługują na uwagę. Wewnętrzne drzwi wahadłowe zazwyczaj w polskich kościołach bywały skromne, najczęściej sporządzone z drewna i pozbawione dekoracji figuralnej, toteż koncepcję ich szczególnie bogatego opracowania należy uznać za zjawisko wyjątkowe i godne odnotowania ${ }^{1}$.

Po zniszczeniach doznanych w czasie II wojny światowej katedra poznańska została odbudowana w latach 1946-1956 według projektu Franciszka Morawskiego w formie gotyckiej z przełomu XIV i XV w. ${ }^{2}$ W 1950 roku, w ostatniej fazie odbudowy zrekonstruowano także kruchtę południową pochodzącą z XIV w. i później wielokrotnie przebudowywaną. Nadano jej formę nawiązującą, odmiennie niż całość budowli, do stanu z początków XIX wieku³.

1 Autorka artykułu pragnie podziękować prof. Tadeuszowi Żuchowskiemu za cenne sugestie i uwagi związane $\mathrm{z}$ redakcją niniejszego tekstu.

2 Katedra poznańska to budowla gotycka wzniesiona na miejscu świątyni przedromańskiej i romańskiej, przebudowana w okresie baroku (Sz. Skibiński, Katedra poznańska, Poznań 2001).

${ }^{3}$ Pomieszczenie zniszczone i odbudowane po 1790 r., ponownie zniszczone w 1945 r. i odbudowane po 1950 r. w stylu nawiązującym do jego ostatniej przebudowy z przełomu 

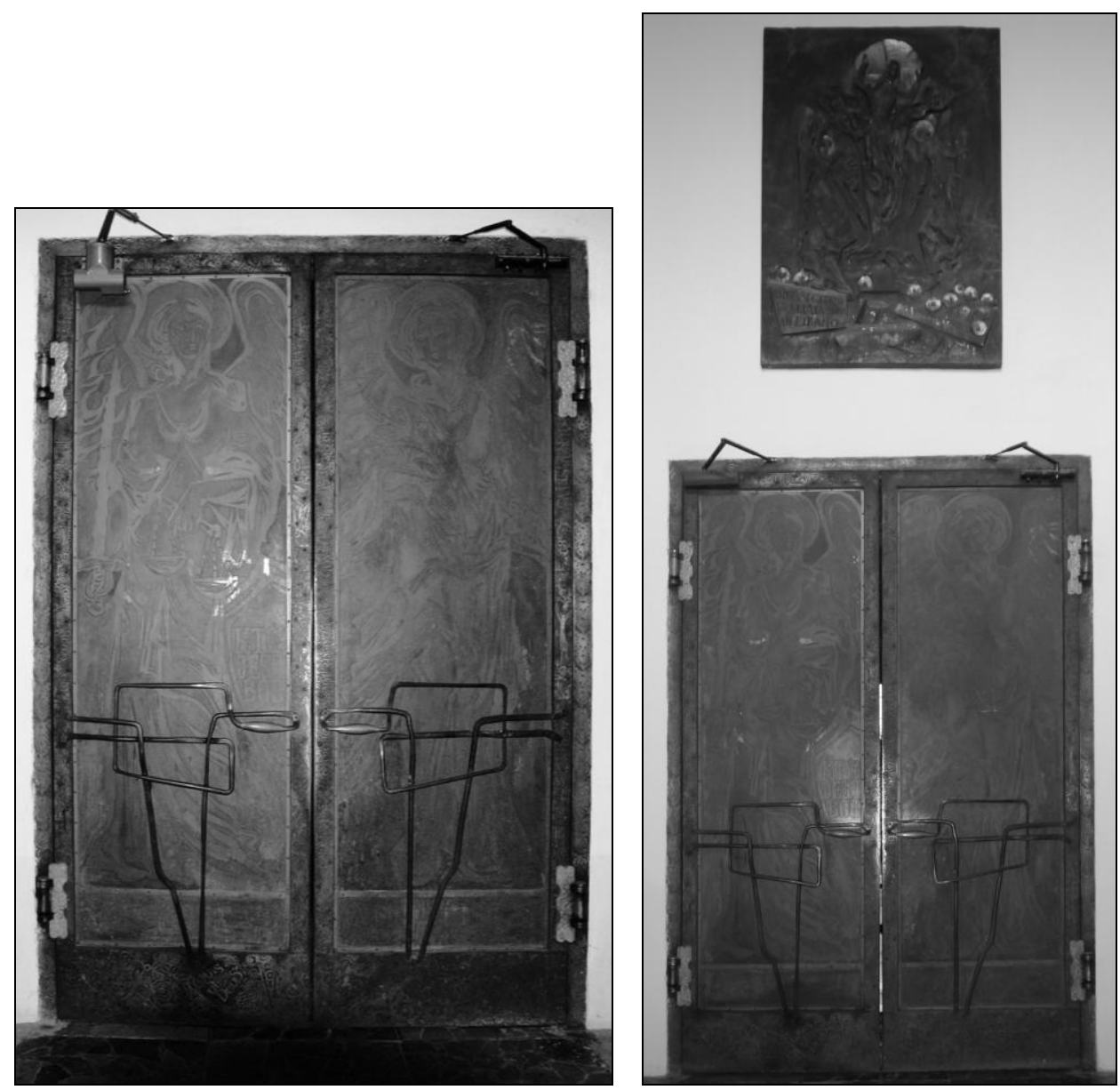

1a, 1b. Ireneusz Daczka, Bogdan Fijałkowski, wewnętrzne drzwi wahadłowe w kruchcie południowej katedry poznańskiej, 1972, trawiona płyta mosiężna patynowana na brąz. Fot. M. Piera

Finalizując odbudowę katedry poznańskiej w 1970 roku dla uczczenia milenium Chrztu Polski kapituła katedralna podjęła decyzję o wykonaniu odlanych w brązie wrót przeznaczonych do portalu w elewacji frontowej (zachodniej) odbudowanej świątyni jako swoistego dopełnienia Drzwi Gnieźnieńskich ${ }^{4}$.

XVIII i XIX w. We wnętrzu kruchty nie zdecydowano się odtworzyć jej pierwotnej gotyckiej formy (Katalog zabytków sztuki. Seria nowa, t. VII Miasto Poznań, cz. 1 Ostrów Tumski i Śródka z Komandoria, red. E. Linette, Z. Kurzawa, Warszawa 1983).

${ }^{4}$ Ibidem, s. 11; Ks. W. Lippa, Wspótczesne drzwi brązowe w katedrach polskich, praca magisterska napisana pod kierunkiem prof. dr hab. Jana Wiktora Sienkiewicza w Katedrze Kultury Artystycznej KUL, Lublin 2006, s. 50-54; informacja o nawiązaniu do śred- 
Prace przygotowawcze trwały długo $\mathrm{w}$ związku z dyskusjami między członkami Komisji Archidiecezjalnej ds. Sztuki Kościelnej, Kapitułą Katedralną i artystą nad treścią i formą przedstawień, ale przede wszystkim z powodu problemów ze zdobyciem materiału i znalezieniem odlewnika, gdyż państwowe firmy odmawiały przyjęcia zamówienia, a właściciele nielicznych zakładów prywatnych nie dysponowali odpowiednimi warunkami ${ }^{5}$. Wobec piętrzących się trudności i groźby niemożności zrealizowania pierwotnego zamysłu, w 1972 roku wyrażono zgodę na propozycję ks. Stefana Tomaszkiewicza ${ }^{6}$, kierującego pracami budowlanymi na terenie katedry, aby wykonać przynajmniej drzwi do kruchty, a wobec mniejszej wagi przedsięwzięcia pozostawiono mu wolną rękę w doborze przedstawień.

Ks. Tomaszkiewicz zwrócił się z prośbą o współpracę do ks. Bolesława Dzierwy ${ }^{7}$, działającego w Komisji ds. Sztuki Kościelnej w diecezji

niowiecznej tradycji reprezentowanej przez Drzwi Gnieźnieńskie w liście ks. Mariana Lewandowskiego, ówczesnego dyrektora Muzeum Diecezjalnego w Poznaniu do ks. Wojciecha Lippy, Poznań, 4 listopada 2005 r. 1. dz. 1-728/05 (Archiwum prywatne ks. W Lippy).

${ }^{5}$ Ostatecznie po 1975 roku kapituła urządziła w jednym z poznańskich fortów własną odlewnię katedralną, w której zatrudniono odlewnika M. Ławniczaka. Autorem drzwi był Kazimierz Bieńkowski, a udało się je ukończyć i zamontować dopiero w 1980 roku (Kazimierz Bieńkowski. Rzeźba, projekty i szkice. Katalog wystawy. Muzeum Archidiecezji Warszawskiej, 24 lutego-25 marca 1997, wstęp T. Dziubecki, Warszawa 1997).

${ }^{6}$ Ks. Stefan Tomaszkiewicz (1917-1992), administrator kościoła św. Marcina z Tours w Donaborowie (1954-1959), proboszcz parafii św. Florianach w Wirach (1959-1964), a następnie magister fabricae ecclesiae przy katedrze poznańskiej i kustosz Muzeum Archidiecezjalnego w Poznaniu. Kierował konserwacją licznych dzieł sztuki sakralnej; od 1979 r. członek komisji czuwającej nad konserwacją obrazu Matki Boskiej Częstochowskiej na Jasnej Górze, autor kilku publikacji z zakresu konserwacji zabytków, twórca projektów polichromii (m.in. w 1969 r. zaprojektował polichromię do kościoła Matki Boskiej Częstochowskiej w Latowicach), wystroju wnętrz sakralnych, a nawet sztandarów kościelnych (na podstawie danych udostępnionych w Muzeum Archidiecezjalnym w Poznaniu; http:// www.parafialatowice.pl/index.php/historia/historia-kocioa-po-1945 z 9 XII 2013; http:// www.opiekun.kalisz.pl/index.php?dzial=artykuly\&kat=swiatyniediecezji\&id=64 $\quad \mathrm{z} \quad 9 \quad$ XII 2013).

7 Ks. Bolesław Dzierwa (1926-2003), wikariusz (1969), a następnie proboszcz (1980) parafii św. Andrzeja Boboli w Szubinie, Przez pewien czas pełnił również funkcję prokuratora (ekonoma) i wykładowcy w Prymasowskim Wyższym Seminarium Duchownym w Gnieźnie. Jako konserwator zabytków w katedrze gnieźnieńskiej (od 1963) kierował pracami konserwatorskim prowadzonymi w świątyni przywracając jej gotycki wystrój. Był członkiem diecezjalnej Komisji Konserwacji i Budowy Kościołów, odpowiedzialnym za opiekę nad zabytkami należącymi do diecezji gnieźnieńskiej. Jako kustosz katedralnych zbiorów sztuki (1989) zorganizował Muzeum Archidiecezji Gnieźnieńskiej i do 2002 r. pełnił funkcję jego dyrektora (Ks. J. Kasprowicz, Biogramy znamienitych kapłanów. Ks. Bolesław Dzierwa, Parafia św. Jakuba Apostoła w Mogilnie. http:// www. faramogilno.pl/ 
gnieźnieńskiej. Ks. Dzierwa był już wtedy jedną z osób najbardziej zaangażowanych we wszystkie prace prowadzone w katedrze gnieźnieńskiej i chętnie dzielił się zdobytym doświadczeniem z innymi kapłanami, także czuwającymi nad odbudową katedry poznańskiej. Podobnie jak ks. Stefan Tomaszkiewicz studiował na Wydziale Konserwacji i Zabytków (obecnie Sztuk Pięknych) Uniwersytetu Mikołaja Kopernika w Toruniu. Po studiach, które obaj duchowni ukończyli mniej więcej w tym samym czasie, ks. Dzierwa (1963) wrócił do Gniezna, gdzie kierował pracami konserwatorskim prowadzonymi w katedrze, przywracając jej gotycki wystrój.

Należy podkreślić, że ze szczególną pieczołowitością traktował wszystkie przedsięwzięcia związane z postacią św. Wojciecha i, zapewne przez analogię do Porta Regia $z$ Gniezna, był też inspiratorem powstania drzwi $\mathrm{z}$ przedstawieniami figuralnymi $\mathrm{w}$ kościołach związanych $\mathrm{z}$ tym świętym $^{8}$. Natomiast ks. Tomaszkiewicz, który uzyskał dyplom w rok później (1964) został skierowany do katedry poznańskiej i delegowany przez Kapitułę Katedralną jako magister fabricae ecclesiaedo nadzorowania wszelkich prac konserwatorskich i inwestycji podejmowanych na terenie katedry. Obaj księża współpracowali ze sobą i konsultowali się, podejmując kolejne przedsięwzięcia dotyczące odbudowy obu katedr i ich wystroju, a o ich bliskich kontaktach może świadczyć zachowana korespondencja oraz relacje osób, które pamiętają tamte czasy ${ }^{9}$. Obaj duchowni śledzili rozwiązania stosowane w powojennej odbudowie obiektów sakralnych nie tylko w Polsce, a na łamach specjalistycznych czasopism naukowych publikowali artykuły będące plonem prac podejmowanych przez nich samych ${ }^{10}$.

/ksbdzierwa.htm z 10 V 2012; B. Gozdowska, Pogrzeb śp. Ks. kan. Bolesława Dzierwy, http://www.archidiecezja.pl/aktualnosci/archiwum/2003/luty/pogrzeb_sp._ks._kan._b._dzier wy.html z 12 V 2012).

${ }^{8} \mathrm{Ks}$. Dzierwa zainicjował powstanie drzwi z przedstawieniami figuralnymi w kościele św. Wojciecha w Wieleniu (ze względu na patrocinium bohatera Drzwi Gnieźnieńskich) i św. Mikołaja w Inowrocławiu (w tym kościele podczas wojny były przechowywane relikwie św. Wojciecha). Ks. Dzierwa miał duży wpływ na treść tych przedstawień oraz polecił ich wykonawców Daczkę i Fijałkowskiego. Duchowny ten dwukrotnie czuwał nad restauracją relikwiarza Św. Wojciecha: po 1945 r. i w 1987 r., gdy uległ zniszczeniu w czasie rabunku w 1987. Z jego inicjatywy wzbogacono relikwiarz o postaci czterech stanów i konfesję. (http://www.inofara.pl/?historia,19 z 2806 2010).

9 Rozmowa z ks. Marianem Lewandowskim (24 VI 2010) i Ireneuszem Daczką (12 VI 2010); Archiwum Archidiecezjalne w Poznaniu, 0143 SOP 177/7, Tomaszkiewicz Stefan, ks. kan., różne, dotyczy spraw architektury; 0143 SOP 177/8 Tomaszkiewicz Stefan, ks. kan., korespondencja, 0143 SOP 177/14, Tomaszkiewicz Stefan, ks. kan., Różne notatki, 0143 SOP 177/15, Tomaszkiewicz Stefan, ks. kan., Różne notatki.

$10 \mathrm{Ks}$. S. Tomaszkiewicz, Wspomnienia konserwatora o odkryciach $w$ malarstwie i rzeźbie Wielkopolski, „Ars sacra et restauratio”, konferencja zorganizowana przez Stowa- 
Ks. Dzierwa nie tylko zaproponował zastosowanie w drzwiach do kruchty poznańskiej techniki trawienia w metalu, łatwiejszej do zrealizowania $\mathrm{w}$ ówczesnych warunkach niż odlew w brązie, ale też uczestniczył w ustaleniu programu ikonograficznego przedstawień. W wyniku współpracy obu duchownych powstała oryginalna koncepcja ikonograficzna dekoracji kruchty oparta na symbolice angelistycznej, chrystologicznej i mariologicznej, w której obok przedstawień wykorzystano teksty w językach: polskim, łacińskim i greckim.

Projekt i realizację drzwi, płaskorzeźby i pozostałych elementów wystroju kruchty powierzono Ireneuszowi Daczce ${ }^{11}$ (poleconemu już wcześniej przez ks. Dzierwę), który od pewnego czasu wykonywał drobne prace dla Muzeum Archidiecezjalnego i katedry poznańskiej. Koncepcję formalnego rozwiązania całości artysta przygotował wraz z Bogdanem Fijałkowskim ${ }^{12}$, kolegą ze studiów, z którym współpracował też przy innych realizacjach. Projekt został zatwierdzony przez ks. Lucjana

rzyszenie Konserwatorów Zabytków, Komisję Episkopatu ds. Sztuki Sakralnej i Klasztor OO. Paulinów na Jasnej Górze 5-7 grudnia 1991 r. Oprac. tekstu: E. Kowalczyk, s. 94n.; Ks. S. Tomaszkiewicz, Podstawowe wiadomości z konserwacji wymagane od kierownika muzeum kościelnego i rektora kościoła, „Archiwa, Biblioteki i Muzea Kościelne” 1987, LIV, s. 78-81; Ks. S. Tomaszkiewicz, Muzeum Archidiecezjalne w Poznaniu, op. cit., s. 119-121.

11 Ireneusz Daczka (ur. 1942 r.) wykonał drzwi do kruchty katedralnej w Poznaniu we wczesnym okresie twórczości, niedługo po ukończeniu studiów w PWSSP w Poznaniu (obecnie Uniwersytet Artystyczny), w pracowni rzeźby prof. Bazylego Wojtowicza w $1970 \mathrm{r}$. (dyplom z wyróżnieniem, z rzeźby architektonicznej). Niecodzienna i rzadko stosowana technika trawienia w metalu zastosowana w drzwiach do Poznania wpisuje się w specyfikę twórczości artysty, który często eksperymentował z nowymi materiałami rzeźbiarskimi i rzadko stosowanymi, nietypowymi technikami. Równolegle Daczka wykonywał w podobnej technice drzwi do kościoła św. Mikołaja w Inowrocławiu oraz, niedługo potem - drzwi do kruchty w kościele św. Wojciecha w Wieleniu Zaobrzańskim (A. Przewoźny, Niezwykła twórczość Ireneusza Daczki, http://www.leszno.interbit.pl/daczka.htm z dnia 10.09.2010, Ireneusz Daczka, Wielkopolski Związek Artystów Rzeźbiarzy http://www.wzar.pl/artysci /ireneusz-daczka, z 10.09.2010).

12 Bogdan Fijałkowski, współpracujący z Daczką przy wykonaniu drzwi do kruchty katedry poznańskiej oraz do kościoła w Inowrocławiu to absolwent poznańskiej PWSSP; w 1980 r. wyemigrował do Australii. W swojej twórczości malarskiej reprezentował kierunek koloryzmu polskiego. Jego samodzielne prace są w Polsce mało znane. (Bogdan Fialkowski, „Puls Polonii”, www.zrobtosam.com/PulsPol/Puls3/index.php?sekcja=1\&arty_id= 7864, z 10.08.2012). Biorąc pod uwagę typowo malarski charakter kompozycji na drzwiach w poznańskiej kruchcie, można by mniemać, że jego wkład w powstanie ostatecznego kształtu przedstawień był znaczny, gdyby nie to, że rzeźby wykonane samodzielnie przez Daczkę mają również niespokojną, żywiołową i malarską formę bliską przedstawieniom na drzwiach. Należy przypuszczać, ze wspólne studia i praca oraz podobieństwo temperamentu artystycznego pozwoliło obu twórcom uzyskać jedność stylu nie do odróżnienia bez dogłębnych badań i analiz. 
Haendsche ${ }^{13}$, kanclerza Kurii Metropolitarnej w Poznaniu, kierującego Komisją ds. Sztuki Kościelnej przy Poznańskiej Kurii Archidiecezjalnej i wykonany w ciągu kilku miesięcy tego samego 1972 roku w pracowni artysty w Rydzynie. Drzwi i tablicę zamontowano w kruchcie południowej, finalizując aranżację wystroju tego skromnego, niewielkiego pomieszczenia.

Należy jednak odnotować, że drzwi te nie zachowały się w całości w stanie z 1972 roku. Pierwotnie bowiem przewidywano, że ich skrzydła będą miały formę ram metalowych wypełnionych taflami szkła z przedstawieniami trawionymi. Zastosowanie takiej techniki zasugerował ks. Stefan Tomaszkiewicz, opowiadając Ireneuszowi Daczce o przedstawieniach $\mathrm{w}$ trawionym białym szkle $\mathrm{w}$ katedrze w Coventry ${ }^{14}$, wzniesionej obok szczątków świątyni zniszczonej w czasie wojny. Biali aniołowie mieli unosić się na tle wnętrza katedry jak w Coventry: tam symbolicznie pozostawionej w ruinie, w Poznaniu - odbudowanej. Jednak duże szyby w drzwiach wahadłowych okazały się niepraktyczne, po kilku latach uległy zniszczeniu i zostały zastąpione płytami z metalu, $\mathrm{z}$ wytrawionymi identycznymi przedstawieniami ${ }^{15}$. Ponieważ ciężar drzwi się zwiększył, dodano nowe zawiasy, zupełnie niepasujące do całości i stwarzające wrażenie przypadkowości.

Ks. Tomaszkiewicz dostarczył Daczce teksty inskrypcji i monogramów, które miały być umieszczone na bordiurze oraz treść napisu i suge-

13 Ks. infułat Lucjan Haendsche był zwolennikiem wprowadzania nowoczesnych śmiałych rozwiązań plastycznych do historycznych wnętrz kościelnych (m.in. ołtarz, polichromia i witraże Wacława Taranczewskiego w kościele NMP w Poznaniu). O współpracy Haendschego z Taranczewskim w: P. Taranczewski, Ojciec i ja. Czy jedno jesteśmy? O Wacławie - Ojcu wspomnienie, „Dekada Literacka” 1998, 6-7 (142-143)

$14 \mathrm{Na}$ podstawie rozmowy $\mathrm{z}$ artystą przeprowadzonej 25.04.2010 r. w Coventry „Szklana ściana” ma 70 m wysokości i 45 m szerokości i została ujęta w ramy z brązu. Na niej przedstawiono postaci aniołów i świętych, którzy przyczynili się do chrystianizacji i utwierdzenia chrześcijaństwa w Wielkiej Brytanii. Katedra w Coventry została zbombardowana przez Niemców w 1940 r. Szklany ekran łączy część pozostawioną jako pomnik wojny z nową świątynią (K. Wright, Coventry - Cathedral of Peace: Healing the Wounds of History in International Reconciliation, Bloomington 2012, s. 36-37, 39-62; L. Campbell, Conventry Cathedral: Art and Architecture in Post-War Britain, Oxford 1996).

15 Autorce artykułu nie udało się dotrzeć do zdjęć ukazujących pierwotną wersję drzwi. Obecnie o pierwotnym wyglądzie wizerunków dużych postaci aniołów na drzwiach mogą dać pewne wyobrażenie tylko tak zwane „białe witraże” z postaciami świętobliwych kanoników, zachowane w przeszkleniach czterech okien obejścia katedry i wykonane przez Daczkę również w 1972 roku z wykorzystaniem tej samej techniki [il. 2]. Białe witraże w oknach obejścia katedry poznańskiej i w pierwotnych drzwiach do kruchty południowej to wynik bezpośredniej inspiracji techniką i formą słynnego ekranu z postaciami świętych w Coventry. 
stię zarysu płaskorzeźbionej kompozycji nad drzwiami. Inspiracje do ornamentów roślinnych i wkomponowanych w nie motywów symbolicznych artysta czerpał też z ilustracji w księgozbiorze ks. Dobromira Ziemowita Ziarniaka (1906-1985), proboszcza parafii św. Mikołaja w Inowrocławiu,

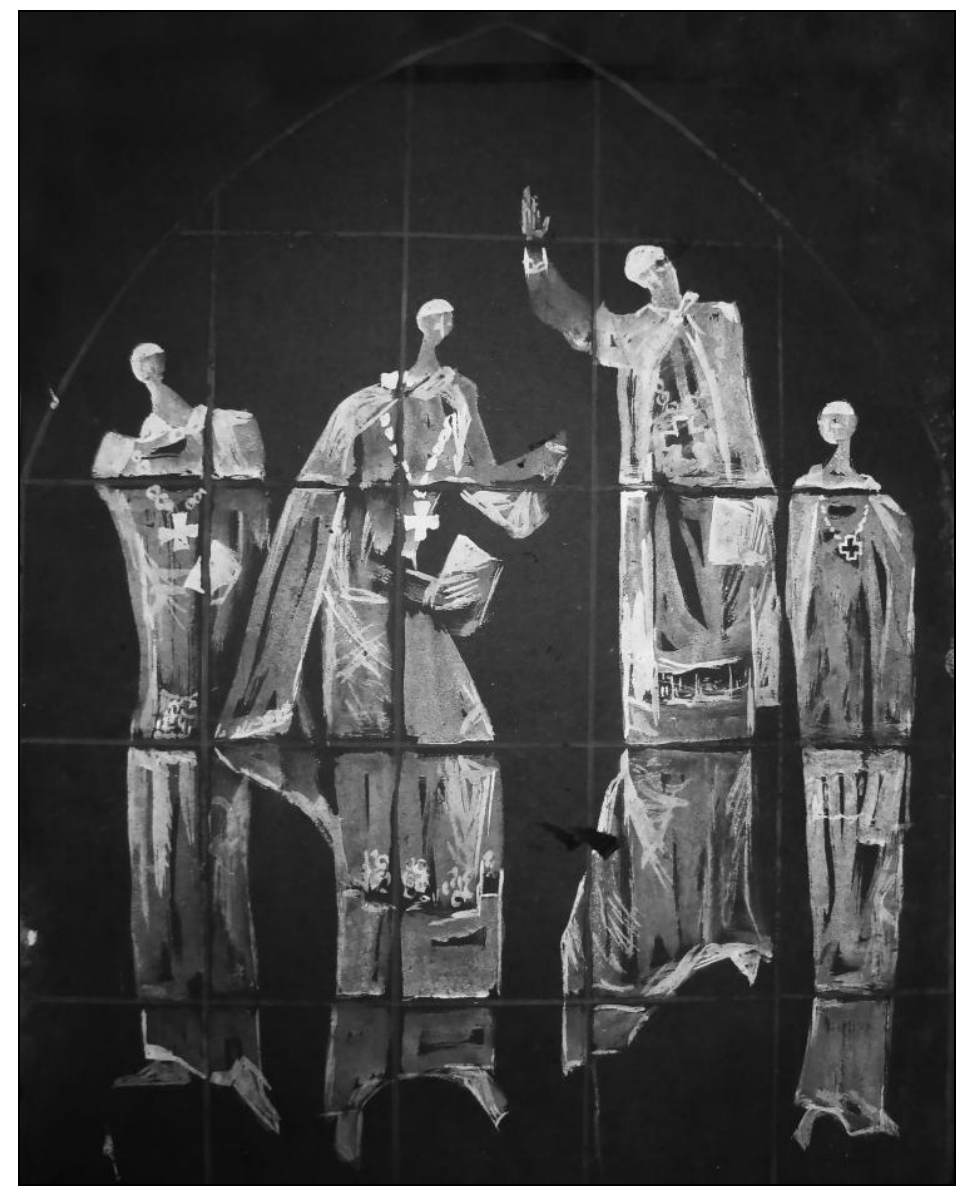

2. Ireneusz Daczka, Kanonicy I, projekt białego witraża do katedry poznańskiej, 1972, tempera na tekturze, własność artysty. Fot. I. Daczka

dla którego wykonywał w tym samym czasie trawione w metalu przedstawienia zdobiące drzwi do kościoła ${ }^{16}$. Ponieważ teksty towarzyszące

${ }_{16}$ Artysta nie jest w stanie zidentyfikować publikacji, z których korzystał. Przyznaje, że jako młodego twórcę interesowały go przede wszystkim kwestie formalne i dopiero w późniejszym okresie życia zaczął przywiązywać większą wagę do symboliki wykonywanych przez siebie przedstawień (rozmowa telefoniczna 2 kwietnia 2015 r.). Koncentracja 
ilustracjom były przeważnie $\mathrm{w}$ języku niemieckim, nieznanym artyście, symbole do dekoracji bordiury drzwi poznańskiej kruchty wykorzystywał bez głębszego poznania ich treści, korzystając tylko z oszczędnych komentarzy właściciela księgozbioru. Wszystkie wprowadzane przez Daczkę motywy były następnie $\mathrm{w}$ miarę tworzenia bordiury uzgadniane $\mathrm{z}$ ks. Tomaszkiewiczem i ks. Dzierwą tak, aby odpowiadały ich koncepcji całości.

Właściwe wejście z kruchty do katedry ma otwór prostokątny. Od strony kruchty ujęte zostało w pilastry zwieńczone trójkątnym przyczółkiem; od strony nawy natomiast znajduje się ono w pseudogotyckiej wnęce licowanej cegłą i zamkniętej łukiem ostrym. Otwór wejściowy wypełniają wykonane w pracowni Daczki dwuskrzydłowe drzwi wahadłowe o wymiarach każdego ze skrzydeł: $262 \mathrm{~cm}$ x $82 \mathrm{~cm}$ (il. 1). Zasadniczym elementem skrzydeł są mosiężne płyty - filungi, których zewnętrzne powierzchnie - awersowa i rewersowa - zostały spatynowane na brąz ${ }^{17}$. Ich powierzchnię pokrywają przedstawienia figuralne wykonane techniką trawienia. Gdzieniegdzie widoczne są ślady rylca, który wykorzystano między innymi do szrafowania tła. Płyty osadzone zostały wertykalnie w mosiężnych ramach, których listwy w dolnej części drzwi są znacznie szersze od pozostałych. Ościeżnice wykonano z tego samego materiału. Zarówno ramy drzwi, jak i ościeżnice zdobi dekoracja ornamentalna, wykonana w podobnej technice.

Uchwyty zrobione $\mathrm{z}$ brązowych prętów, dekoracyjnie wygiętych, tworzą ażurową strukturę przenikających się linearnych zgeometryzowanych form, analogicznie na obu skrzydłach, zarówno na awersie, jak też na rewersie.

Prostokątna tablica nad drzwiami, zawierająca płaskorzeźbioną kompozycję, została odlana w brązie. Niektóre jej detale pozłocono (il. 8).

Pole filungu z każdej strony wypełnia jedna postać. Pola z przedstawieniami figuralnymi przypominają matryce akwatinty, a sylwetki sprawiają wrażenie malowanych szerokimi pociągnięciami pędzla, żywiołowo i dynamicznie. Tło nieco cofnięte, poprzez swoją matową powierzchnię pokrytą grubszą warstwą patyny odróżnia się nieco od połyskliwych zarysów postaci. Jej warstwa rozprowadzona nierówno, w różnych częściach płyty nieco odmiennie ulegała procesom patynizacji, wprowadzając do całości dodatkowe efekty kolorystyczne różnych odcieni brązu: od czerwonawych po zielonkawe, a także tonów czerni i jasnego grynszpanu, zacierając jednocześnie przejrzystość rysunku. Przedstawienia figuralne

\footnotetext{
na sprawach formy zapewne była przyczyną braku należytej uwagi prowadzącej do błędów w zapisie niektórych inskrypcji.

17 Według informacji autora drzwi Ireneusza Daczki (Archiwum cyfrowe CDWSzS WS UR w Rzeszowie, Ireneusz Daczka, Ankieta twórcy).
} 
kontrastują z dekoracją bordiur i ościeżnicy wypełnionych drobnym, ale precyzyjne zarysowanym ornamentem. Powstał on w wyniku trawienia tła, ale ostateczny kontur poprawiono za pomocą rylca.

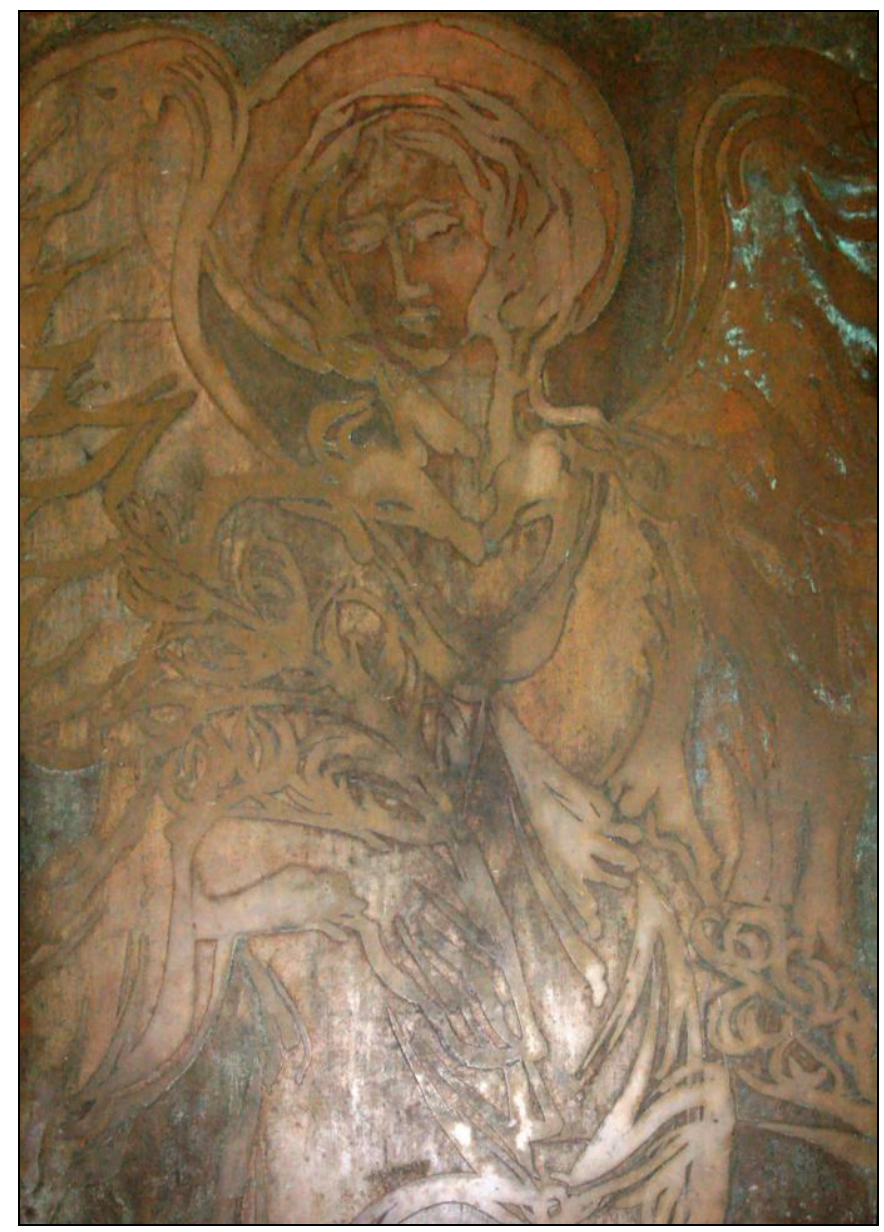

3. Ireneusz Daczka, Bogdan Fijałkowski, Archanioł Michat, 1972, fragment przedstawienia na drzwiach do kruchty południowej, trawiona płyta mosiężna (?) patynowana na brąz, kościół katedralny pw. św. św. Piotra i Pawła w Poznaniu, drzwi do kruchty od strony nawy. Fot. G. Ryba

Przedstawienia na awersie i rewersie drzwi są niemal identyczne, w nawiązaniu do pierwotnej wersji, w której płyciny były wykonane z trawionego szkła. Na skrzydle lewym (od strony kruchty) ukazano: Archanioła Michała z wagą i mieczem o płomienistej głowni (il. 3); natomiast na prawym - Archanioła Gabriela z lilią (il. 4). Otaczającą oba wi- 
zerunki bordiurę wypełnia ornament roślinny z wkomponowanymi weń inskrypcjami oraz przedstawieniami symbolicznymi. Bordiura od strony wnętrza kościoła, choć na pierwszy rzut oka taka sama jak od strony kruchty, różni się od niej w niektórych szczegółach kompozycji.

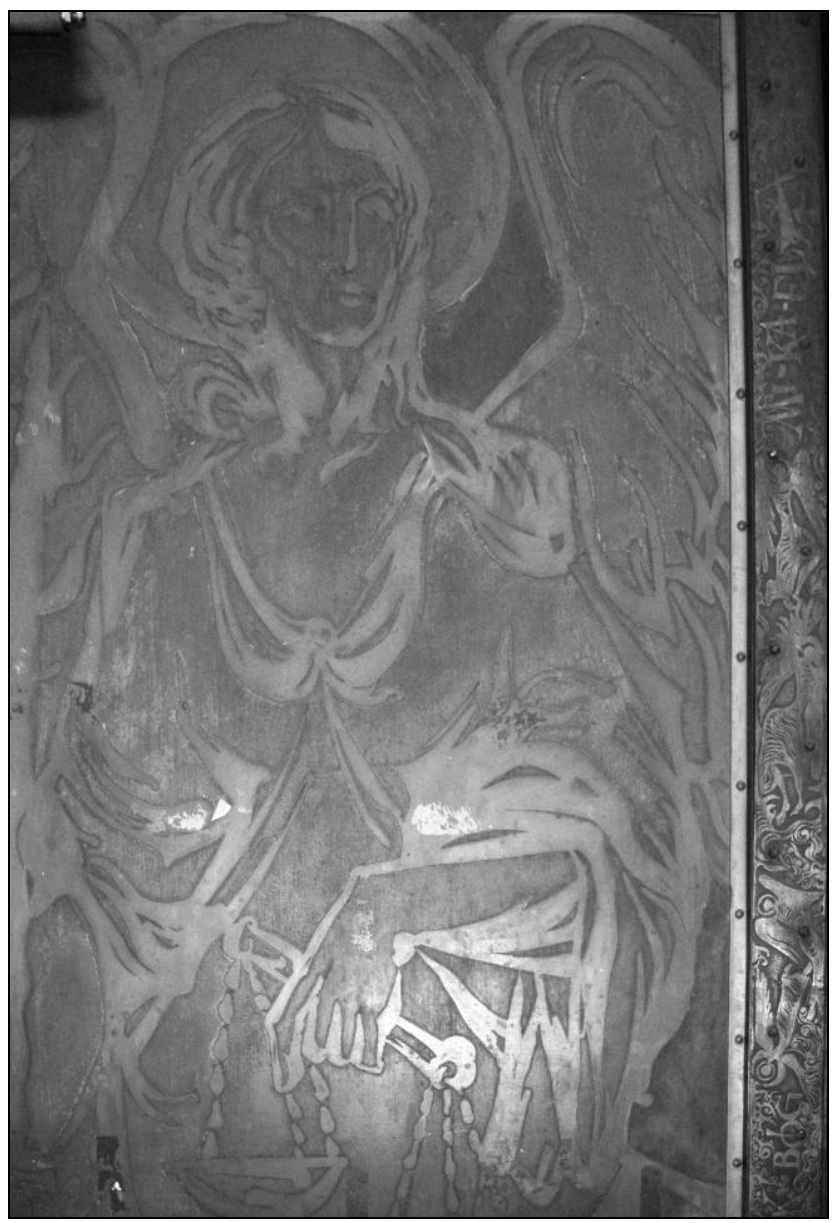

4. Ireneusz Daczka, Bogdan Fijałkowski, Archanioł Gabriel, 1972, fragment przedstawienia na drzwiach do kruchty południowej, trawiona płyta mosiężna patynowana na brąz, kościół katedralny pw. św. św. Piotra i Pawła w Poznaniu, drzwi do kruchty od strony nawy. Fot. G. Ryba

Sylwetka Michała Archanioła została przedstawiona w kontrapoście, zwrócona nieco $\mathrm{w}$ prawo, z głową skierowaną w przeciwną stronę. Jego szaty spływają do ziemi w obfitych malowniczych fałdach, zasłaniając stopy. W prawej ręce, spuszczonej wzdłuż ciała, trzyma miecz tak, że jego 
płomienista głownia uniesiona jest pionowo $\mathrm{w}$ górę; natomiast $\mathrm{w}$ dłoni ugiętej lewej ręki archanioła widnieje waga. Twarz i włosy zostały zaznaczone szkicowo, a wokół głowy zarysowano krąg aureoli. Skrzydła anielskie mieszczą się tylko częściowo w kadrze filungu. Napis KTÓŻ JAK BÓG został umieszczony na wysokości kolan św. Michała przy prawej (wewnętrznej) listwie tuż nad uchwytem. Na listwie górnej bordiury okalającej postać archanioła, patrząc od lewej do prawej, przedstawiono: pelikana karmiącego trzy pisklęta, kiść winogron, sylwetkę jelenia wśród splotów fantastycznych roślin, przechodzących w fale wody otaczające ryby, a następnie - jakby dwie łodzie na morzu. Na szerokiej ramie dolnej wśród ornamentów znajduje się łacińska wersja tekstu towarzyszącego postaci anioła na filungu: QUIS UT DEUS, a obok - otoczony wicią roślinną miecz - atrybut św. Michała, trzymany przez niego w przedstawieniu na płycinie (il. 5).

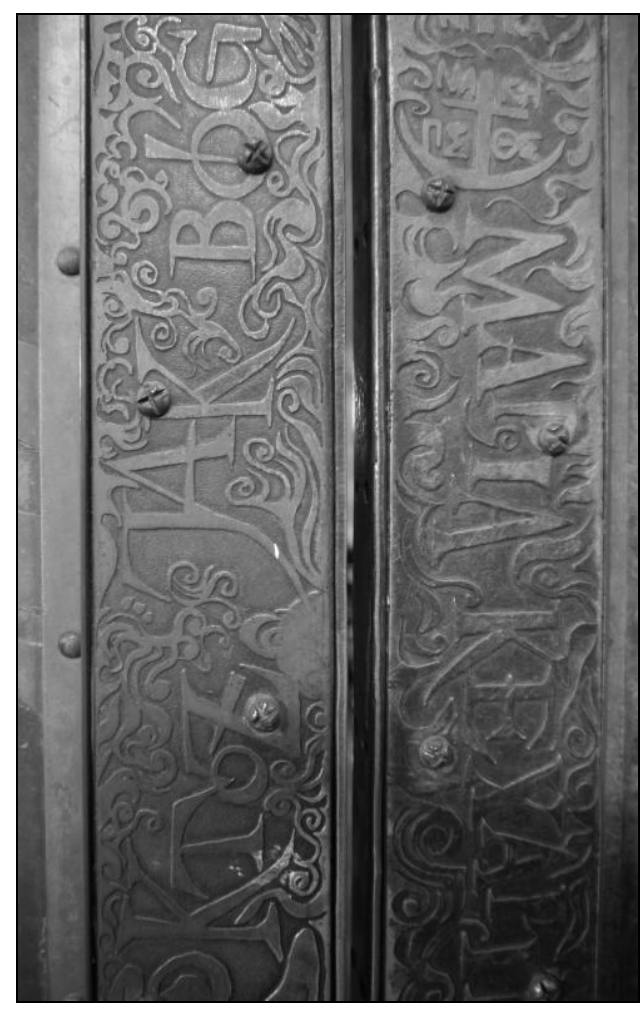

5. Ireneusz Daczka, Bogdan Fijałkowski, Drzwi do kruchty południowej katedry poznańskiej, fragment bordiury z mieczem i napisem QUIS UT DEUS,1972, trawiona płyta mosiężna, patynowana. Fot. G. Ryba

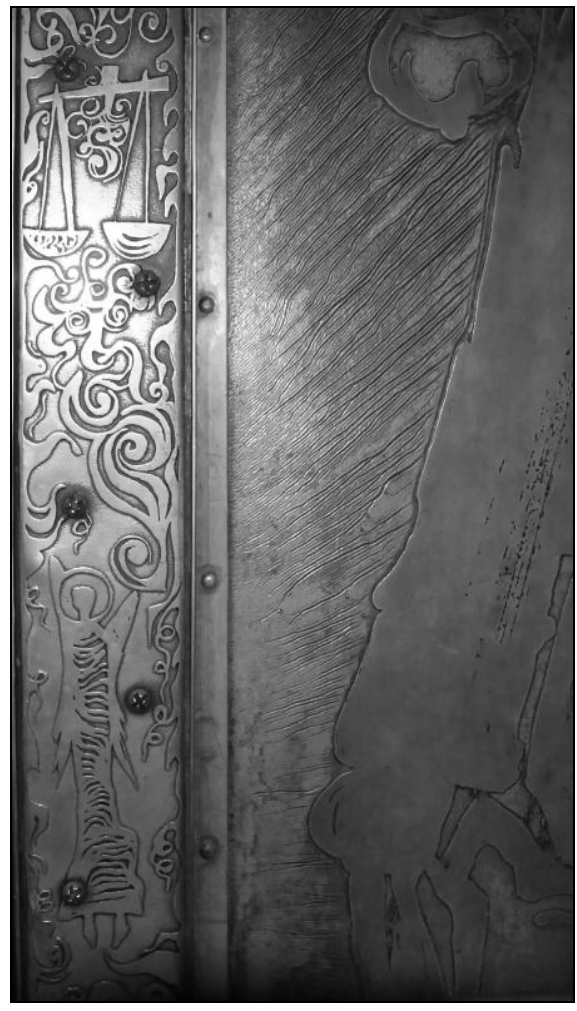

6. Ireneusz Daczka, Bogdan Fijałkowski, Drzwi do kruchty południowej katedry poznańskiej, fragment bordiury $\mathrm{z}$ chrystogramem,1972, trawiona płyta mosiężna, patynowana. Fot. G. Ryba 
Symbole na listwach pionowych przy przedstawieniu tego archanioła należy odczytywać w kierunku wznoszącym od dołu do góry, zgodnie z układem zamieszczonych tam inskrypcji.Listwa zewnętrzna (lewa) ozdobiona została greckim napisem otoczonym ornamentem: IH $\Sigma O Y \Sigma$ XPI $\Sigma T O \Sigma$ (napis zaczyna się powyżej prętów uchwytu i kończy na wysokości rękojeści miecza); wyżej umieszczono: kiść winogron, monogram powtarzający litery $A \Omega+A \omega+\alpha \omega$, zwieńczone krzyżami, chrystogram IHS opisany na krzyżu równoramiennym (il. 6), greckie monogramy połączone

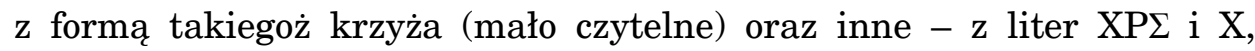
wkomponowane w ornament roślinny, potem (na wysokości głowy Michała) ponownie pojawiają się dwa chrystogramy opisane na krzyżu. Wewnętrzną pionową listwę (prawą) ozdabia ornament roślinny, z którego wyłaniają się postaci aniołów umieszczone jedne nad drugimi. Wyżej znajduje się napis KTÓŻ JAK BÓG (il. 7) odpowiadający przedstawieniu wagi trzymanej przez anioła ukazanego na filungu. Nad napisem widnieją kolejne cztery sylwetki anielskie i kolejny napis umieszczony na wysokości twarzy postaci wyobrażonej wewnątrz obramowania: MI-KA-EL, ponad nim umieszczono ponownie przedstawienie wagi i ornament roślinny.

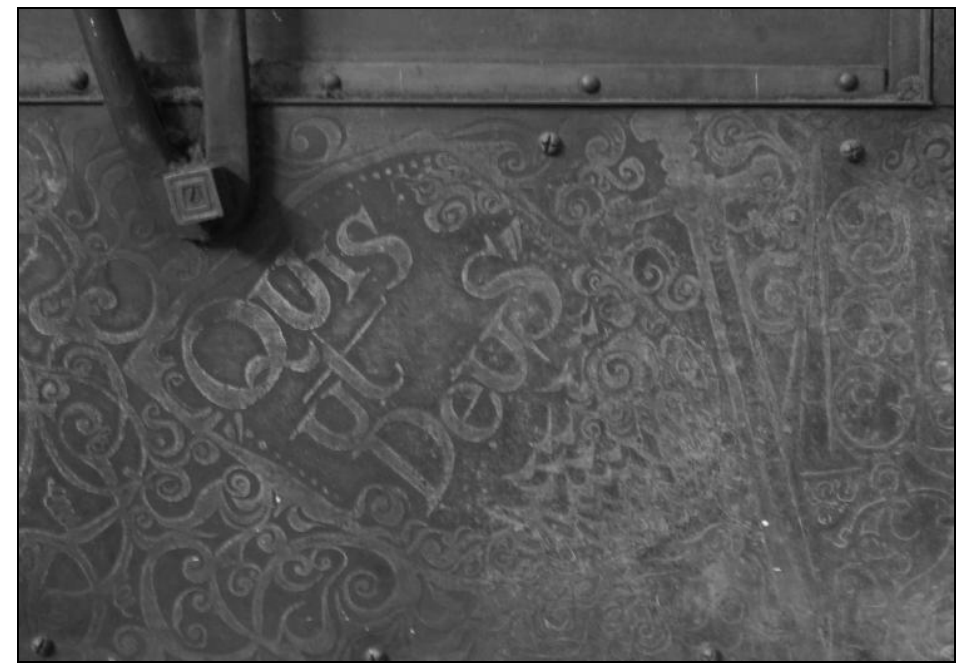

7. Ireneusz Daczka, Bogdan Fijałkowski, Drzwi do kruchty południowej katedry poznańskiej, fragmenty ościeżnic z inskrypcjami, 1972, trawiona płyta mosiężna, patynowana. Fot. M. Piera

Sylwetka Archanioła Gabriela na filungu sąsiedniego skrzydła została ukazana $\mathrm{w}$ ujęciu frontalnym $\mathrm{w}$ pofałdowanych rozwianych szatach z lekko ugiętą nogą sugerującą ruch. Archanioł w prawej ręce trzyma li- 
lię, natomiast druga ginie $\mathrm{w}$ fałdach szat. Podobnie jak w przedstawieniu Michała jego twarz została potraktowana szkicowo, głowę otacza aureola, skrzydła tylko częściowo mieszczą się w obrębie płyciny, a stopy kryje draperia ${ }^{18}$. Na listwie poziomej nad głową Gabriela umieszczono wśród ornamentów fitomorficznych przedstawienia jelenia oraz ryb, natomiast na dole szeroki pas bordiury wypełniają wyłącznie dekoracyjne wici roślinne. Układ symboli na listwach pionowych przy przedstawieniu tego archanioła należy odczytywać w porządku zstępującym, od góry do dołu, zgodnie z układem inskrypcji.

$\mathrm{Na}$ listwie wewnętrznej (lewej) pod monogramem: IHS na wysokości ramion archanioła i pąków na szczycie łodygi lilii znajduje się: grecki napis $\mathrm{IH} \Sigma \mathrm{O} \gamma \Sigma$ XPI $\Sigma \mathrm{TO} \Sigma$, monogramy chrystologiczne: dwa krzyże, pod nimi: I $\Sigma \mathrm{X} \Sigma^{19}$; między ramionami krzyża równoramiennego ponownie: $\mathrm{I} \Sigma \mathrm{X} \Sigma$ NIKA oznaczający Chrystusa Zwycię$z c e ̨$; między ramionami krzyża wspartego na kotwicy - litery częściowo zatarte oraz inskrypcja KEXAPIT-

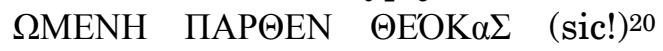
(il. 7), przechodząca w wić roślinną. Napis ten zaczyna się w połowie bordiury i odpowiada zakończeniu łodygi lilii trzymanej przez Gabriela na filungu.

8. Ireneusz Daczka, Bogdan Fijałkowski, Drzwi do kruchty południowej katedry poznańskiej, fragment bordiury $\mathrm{z}$ przedstawieniem anioła i wagi, 1972, trawiona płyta mosiężna, patynowana. Fot. G. Ryba

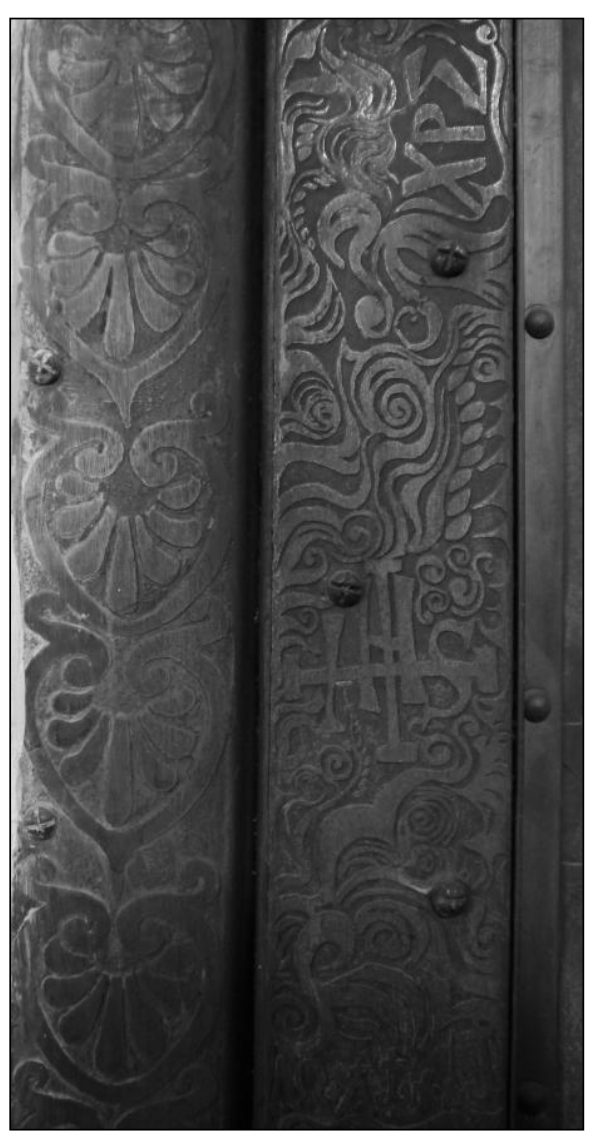

18 Postaci w płycinach, a w szczególności sylwetka Gabriela przypominają kompozycyjne ujęcie aniołów z obrazów Dolabelli w kaplicy św. Jacka w kościele dominikanów w Krakowie.

${ }_{19}$ Monogram zapisany w formie wczesnochrześcijańskiej z wykorzystaniem $\Sigma$ (sigma) zastąpionej w średniowieczu przez C.

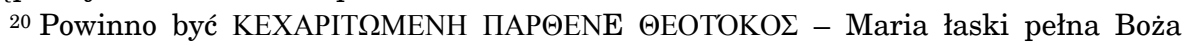
Dziewica. 
Zewnętrzny (prawy) pas bordiury zdobi inskrypcja: LEKARSTWO BOŻE. Poniżej umieszczono trzy ryby oraz sylwetkę anioła z rozwiniętymi skrzydłami i złożonymi w dole dłońmi. Jeszcze niżej w zwoje ornamentu zostały wkomponowane kolejne postaci anielskie.

$\mathrm{Na}$ bordiurze drzwi od strony wnętrza kościoła (na rewersie) na obramieniu płyciny z postacią św. Michała powtórzono motywy dekoracyjne zdobiące ją od strony kruchty (na awersie), ale ograniczono ilość inskrypcji i monogramów na rzecz motywów ornamentalnych (il. 8). Natomiast wokół płyciny z Archaniołem Gabrielem na rewersie w dekoracji listwy górnej wprowadzono krzyże, kiście winogron, kosz z chlebem i ryby, na dolnej zamieszczono duże przedstawienie ryby, a w pasie bordiury listwy prawej (wewnętrznej) zamiast greckiego napisu maryjnego na awersie wśród splotów roślinnych zamieszczono różnorodne formy krzyża (franciszkański, laskowany, jerozolimski, monogram gwiaździsty, krzyż monogramatyczny).

Natomiast ościeżnice drzwi pokrywa motyw roślinny, nawiązujący do typowego greckiego ornamentu palmetowego. Jego regularna rytmiczna forma odbiega od stylistyki dekoracji zdobiącej skrzydła drzwi (il. 6).

Przedstawienia na bordiurze są dekoracyjnie stylizowane, a największe zagęszczenie inskrypcji i motywów symbolicznych znajduje się na listwach pionowych, na linii wzroku patrzącego. Zestawienie różnorodnych form krzyża przypomina ilustrację odpowiedniego hasła w słowniku symboli religijnych, na który zapewne natknął się młody artysta w księgozbiorze ks. Ziarniaka.

Archaniołowie ukazani na drzwiach w kruchcie katedry poznańskiej symbolizują początek i koniec dziejów zbawienia ${ }^{21}$. Gabriel stoi u jego początków jako zwiastujący Marii narodziny Jezusa, a Michał ma być obecny przy Sądzie Ostatecznym na końcu świata. Ich wizerunki bywały umieszczane przy wejściu do świątyni jako strzegące przed siłami zła ${ }^{22}$.

Michał to archanioł Bożej sprawiedliwości, sądu, łaski i zlitowania ${ }^{23}$. Twórca drzwi do kruchty katedry poznańskiej wybrał typ przedstawienia z mieczem - symbolem zwycięstwa nad szatanem i sprawiedliwości oraz z

21 Autorzy programu ikonograficznego nie wybrali patronów świątyni, gdyż ci byli przewidywani w przedstawieniach dekoracji wejścia głównego.

22 Obaj stoją także przy tronie Chrystusa lub Marii; bywają ukazywani jako strażnicy Raju lub Świętego Świętych. R. Knapiński, Titulus ecclesiae. Ikonografia wezwań wspótczesnych kościołów katedralnych w Polsce, Warszawa 1999, s. 340; D. Estivill, Aniołowie, (w:) Nowy leksykon sztuki chrześcijańskiej, Kielce 2012, s. 56-63 (tam szersza bibliografia).

${ }^{23}$ G. Duchet-Suchaut, M. Pastoureau, La Bible et les saints. Guide iconographique, Paris 1990, s. 231-232; Ks. Z. Ziółkowski, Michał Archanioł w Piśmie Świętym i życiu Kościoła, Warszawa 2011; Knapiński, op. cit., s. 332-344; M. Bussagli, Aniołowie: pochodzenie, historia, ikonografia istot niebieskich, tłum. A. Gogut, Warszawa 2011, s. 748-752. 
wagą, na której archanioł odmierza ciężar dobrych i złych uczynków zmarłego jako towarzysz umierających, wskazujący ich duszom drogę ku niebu. Imię Michał oznacza: Któz jak Bóg. Wezwanie to zostało kilkakrotnie powtórzone w różnych językach na obramieniu drzwi do kruchty. Umieszczone obok postaci archanioła słowa są trawestacją tego wezwania, a na bordiurze znajduje się zapis jego imienia we właściwym brzmieniu (Michael). Okrzyk Któż jak Bóg oznacza, że nie ma nikogo ponad Boga i zawiera potrzebę uwielbienia Stwórcy za dar stworzenia. Michał to obrońca przed złem. Według tradycji Kościoła, zwyciężył zbuntowanego szatana (Jud 9) i stoczy z nim ostateczną walkę u kresu czasów (Ap 12.7). W doczesności Michał jest wzywany na pomoc przeciw zasadzkom sił zła. Waga i miecz to także atrybuty, które zamieszczono na bordiurze obok płyty z postacią tego archanioła. Miecz i liczne sylwetki anielskie wkomponowane $\mathrm{w}$ sploty bordiury mają zapewne przypominać walkę Michała na czele zastępów niebieskich ze zbuntowanymi aniołami. Miecz i waga symbolizują również sprawiedliwy sąd.

Gabriel to „Mąż Boży”24, który oznajmia ludziom przesłanie od Boga. Jest on zwiastunem potężnego działania Boga w sytuacjach według ludzkiej miary niemożliwych bądź przekraczających zdolność pełnego zrozumienia, do których należy tajemnica Bożego wcielenia. Na drzwiach kruchty poznańskiej został przedstawiony z lilią tak, jak w ikonografii chrześcijańskiej bywa ukazywany w scenie Zwiastowania. Gabrielowi odpowiada na bordiurze napis grecki stanowiący fragment słów wypowiedzianych przez niego podczas spotkania z Maryją (Łk 1. 28) i wchodzących w skład modlitwy Pozdrowienia Anielskiego. Lilia oznacza czystość i dziewictwo Madonny, wyrażone słowami w drugiej części poświęconej Jej inskrypcji na bordiurze. Napis ten znajduje się tylko na awersie skrzydła (od strony kruchty). Wchodzący do świątyni poznaje więc Gabriela przede wszystkim jako zwiastuna nowiny o Bożym wcieleniu, natomiast człowiekowi wychodzącemu na zewnątrz jawi się on (na rewersie) raczej jako współopiekun miejsca ${ }^{25}$ otoczony emblematami chrystologicznymi.

$\mathrm{Na}$ bordiurze (listwa pionowa prawa awersu i odpowiednio - lewa rewersu) obok płyty z przedstawieniem Gabriela znajduje się napis Lekarstwo Boże. To znaczenie imienia archanioła Rafała ${ }^{26}$, który został przedstawiony na listwie z rybami jako atrybutem. Archanioł ten przynosi zdrowie duszy, uzdrawia chorych i czuwa na ścieżkach ludzkiego życia (Tb). Wprowadzenie do programu bordiury archanioła Rafała, poprzez

\footnotetext{
${ }^{24}$ Duchet-Suchaut, op. cit., s. 153-154; Bussagli, op. cit., s. 560-614.

${ }^{25}$ Por. przyp. 22.

26 Duchet-Suchaut, op. cit., s. 291-292; Bussagli, op. cit., s. 270-278, 298-306.
} 
przywołanie jego imienia wzbogaca wymowę teologiczną całości przedstawień na drzwiach do kruchty, gdyż Gabriel, Michał i Rafał to trzy Imiona Opieki Bożej, które przypominają, że Bóg nie tylko stworzył świat, ale Jego Opatrzność czuwa nad nim i prowadzi go ku ostatecznej doskonałości 27 .

Pozostałe motywy symboliczne podkreślają wymowę dominujących przedstawień, ale nie tworzą ciągów narracyjnych układających się w sceny alegoryczne. Aby zbudować złożony przekaz ideowy, autor koncepcji ikonograficznej posiłkował się przede wszystkim wprowadzeniem inskrypcji28.

Powtórzony na bordiurze (awers i rewers) przy obu postaciach napis grecki, zawierający pełne imię Jezus i powszechnie łączony z nim tytuł Chrystus oraz liczne greckie i łacińskie monogramy chrystologiczne mają przypominać istotę Słowa wcielonego, nadającego sens całości przedstawień. Pelikan, winna latorośl, ryby i kosz chleba to symbole Chrystusa i Eucharystii. Jeleń i ryby pływające w wodzie łączone bywały z symboliką chrztu, a statek na morzu oznacza bieg życia chrześcijanina. Trzykrotnie powtórzona inskrypcja $\mathrm{A} \Omega$ to wywodzący się przede wszystkim z Nowego Testamentu symbol początku i końca dziejów zbawienia, a także samego Boga (J 1,8; Ap 21,6; Ap 22,13)29.

Odlana w brązie płaskorzeźba umieszczona nad drzwiami przedstawia Wniebowzięcie Matki Bożej, wpisane w drzewo Libanu (il. 9, 10). Po obu stronach drzewa i wznoszącej się nad nim postaci Madonny ukazano dwie sylwetki adorujących Ją aniołów; z przodu poniżej widoczny jest otwarty grób i dwanaście zniczy symbolizujących apostołów, którzy towarzyszyli Wniebowzięciu. Głowę Madonny otacza krąg złotej aureoli; w podobne, nieco mniejsze złote koła wpisują się znicze. Złocone koliste formy kontrastują z ciemną powierzchnią brązu płaskorzeźby. Poszczególne elementy przedstawienia są modelowane za pomocą ostrych niespokojnych linii, dynamizujących kompozycję. Ukazanie Madonny jako „wpisa-

27 To trzej aniołowie kanoniczni jako jedyni znani z imienia występują na kartach Biblii. W 1570 r. zatwierdzono formularz mszy św. ku ich czci. Początkowo Gabriela wspominano 24 marca (w wigilię uroczystości Zwiastowania), Rafała - 24 października, zaś Michała - 29 września. Ta ostatnia data została później przyjęta jako wspólne święto wszystkich archaniołów. W 1969 roku poświęcono wszystkim trzem archaniołom jeden dzień w kalendarzu liturgicznym (vide Estivill, op. cit., s. 60).

28 Jak zauważył prof. T. Żuchowski po wstępnej lekturze niniejszego tekstu: „Symbolika omawianych drzwi jest mało wyrafinowana, a na dodatek wspomagana obficie przez inskrypcje". Dopiero w połączeniu z symboliką zawartą w przedstawieniu na tablicy zamieszczonej powyżej powstaje bardziej złożony przekaz.

${ }_{29}^{2}$ D. Forstner, Świat symboliki chrześcijańskiej, Warszawa 1990, s. 28-30, 180, 246, 264. 
nej w drzewo Libanu"30 oraz przedstawienie apostołów jako świateł zniczy należy uznać za ciekawy i raczej niespotykany motyw w ikonografii Wniebowzięcia.

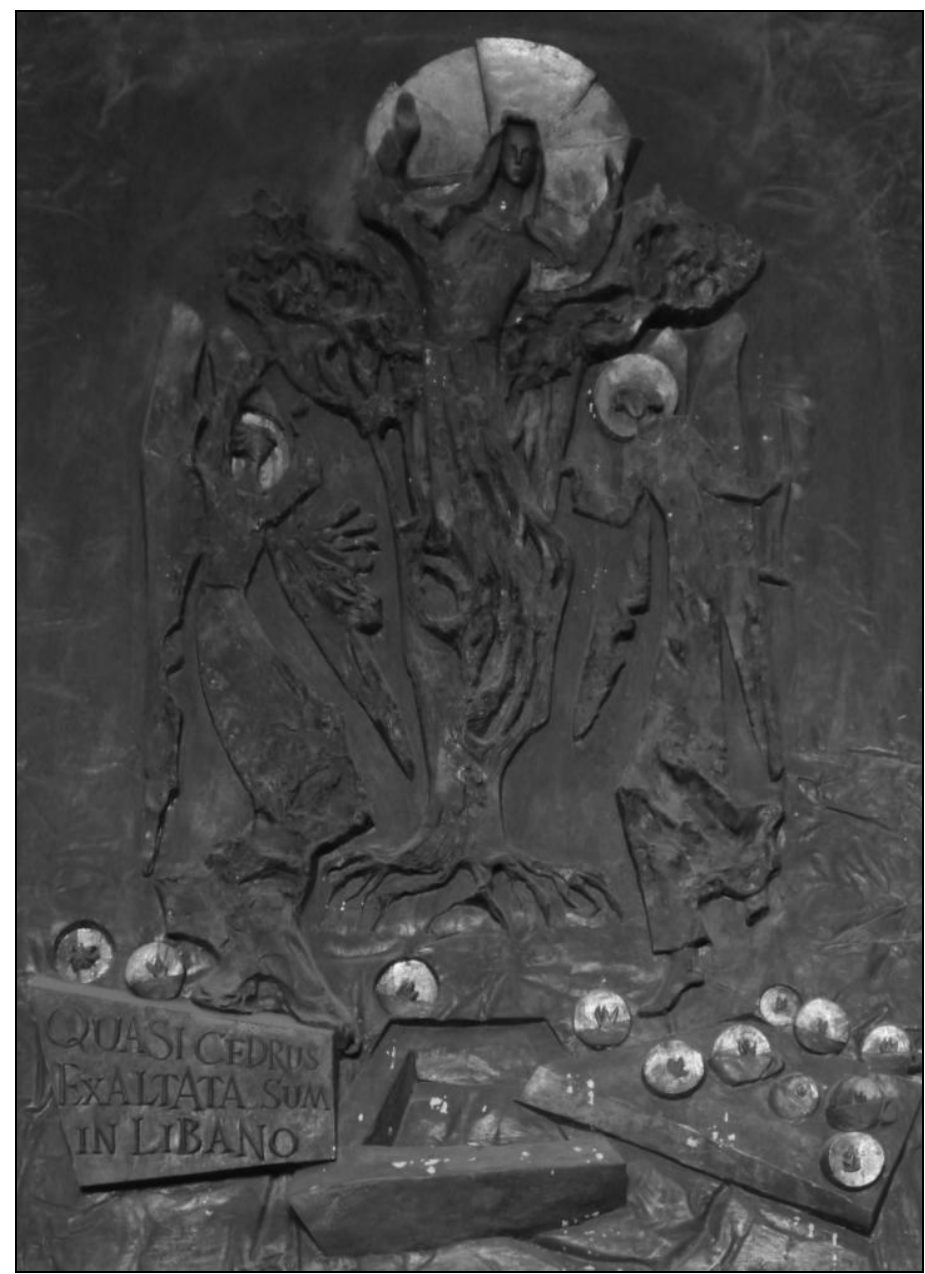

9. Ireneusz Daczka, Wniebowzięcie, płaskorzeźba nad drzwiami do kruchty południowej katedry poznańskiej, 1972, odlew w brązie. Fot. M. Piera

$\mathrm{Na}$ jednej z odsuniętych płyt nagrobnych napisano: „Quasi cedrus ex altata sum in Libano (Wyniesiona jestem $w$ górę, jak drzewo cedrowe na Libanie)" (Syrach 24,17) Są to słowa Mądrości, łączone z osobą Matki Bo-

30 Tak dosłownie miał się wyrazić ks. Tomaszkiewicz w rozmowie z artystą (na podst. wywiadu z I. Daczką z 2 IV 2015). 
żej i wchodzące w skład tekstu odmawianej w południe seksty Godzinek o Niepokalanym Poczęciu Najświętszej Marii Panny. Postaci archaniołów na drzwiach i symbolika bordiury pozwalają także na odniesienia do różnych fragmentów Liturgii Godzin brewiarza. Odpowiednie wersy biblijnego tekstu w czytaniu seksty przypominają, że archanioł Gabriel ukazał się Danielowi jako istota niebiańska o wyglądzie mężczyzny (Dn 8,15). Natomiast zwycięstwo Michała archanioła nad szatanem jest wspominane w czasie jutrzni.

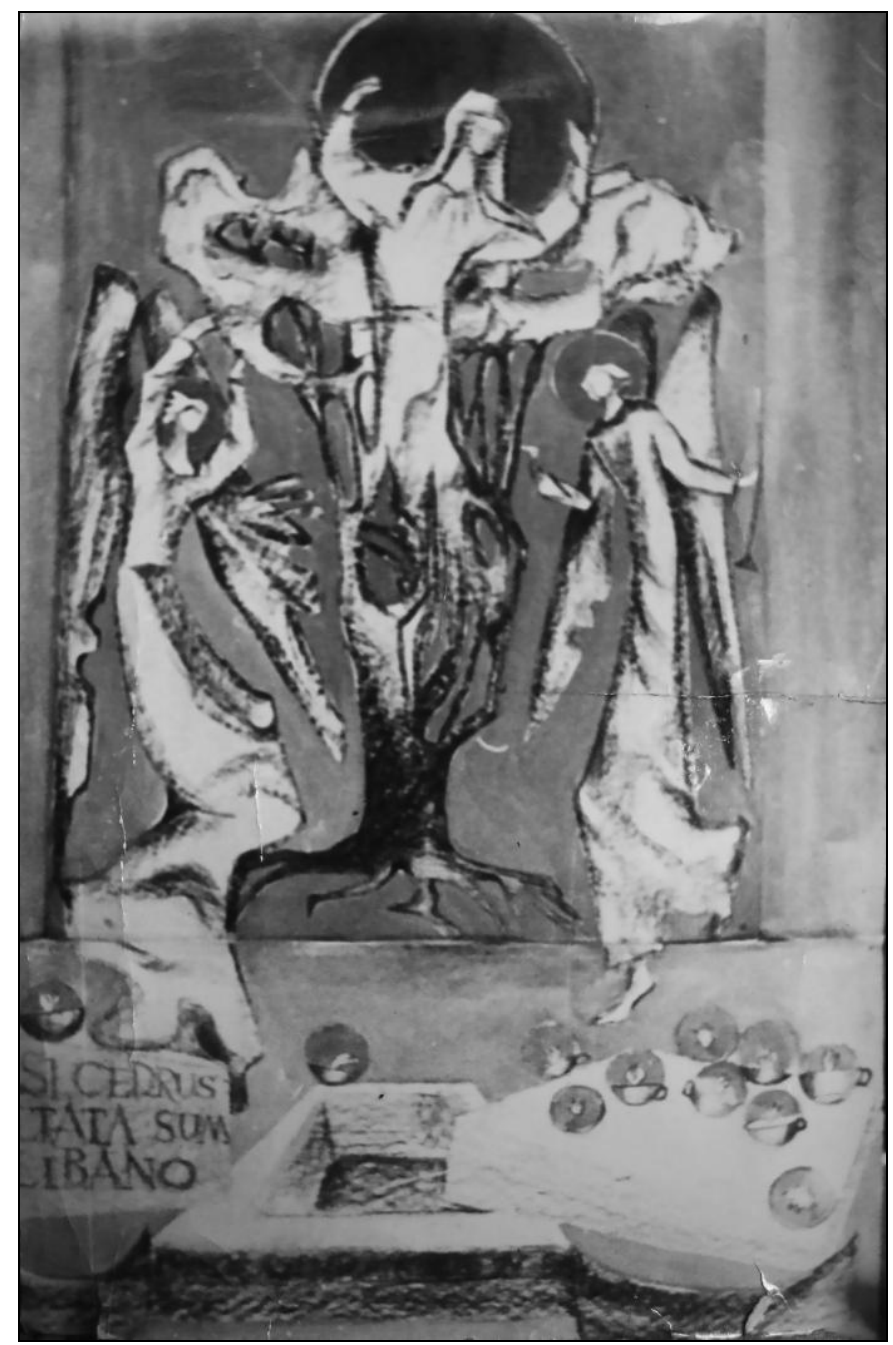

10. Ireneusz Daczka, Wniebowzięcie Matki Boskiej, projekt płaskorzeźby z brązu, 1972, tempera na tekturze, własność artysty. Fot. I. Daczka 
Zwieńczenie drzwi, których ikonografia została zdominowana przez tematykę angelistyczną, płaskorzeźbą ze sceną Wniebowzięcia wskazuje na Maryję jako Królową Aniołów, tytułowaną tak między innymi w wezwaniach Litanii Loretańskiej. Tam też znajduje się odniesienie do Matki Bożej jako „Bramy niebieskiej”. Podobna metafora powtarza się tė̇ w każdej części wspomnianych już Godzinek o Niepokalanym Poczęciu Najświętszej Marii Panny: „Tyś jest świętych drzwiami (...), Tyś nad aniołami” (pryma), „Tyś brama rajska” (tercja), „Brama na wschód wystawiona” (seksta) i ponownie „Brama rajska” (nona).

Drzwi i tablica nad nimi stanowiły najważniejszy element aranżacji wnętrza kruchty, którego dopełnieniem były inne prace: dwie kropielnice z brązu, gablota na ogłoszenia parafialne, wykonana ze szkła i mosiądzu oraz tablica prezentująca dzieje katedry (obecnie nieistniejąca) ${ }^{31}$.

Zapewne niecodzienną dbałość o wystrój pomieszczenie kruchty południowej w katedrze poznańskiej zawdzięcza temu, iż przez nie prowadziła droga z pałacu arcybiskupiego do wnętrza świątyni ${ }^{32}$. Przedstawienia te miały więc służyć nie kontemplacji przeciętnego odbiorcy przekraczającego mury katedry, tylko uczonym biskupom poznańskim i osobom z ich otoczenia rozumiejącym łacinę i grekę, a także biegłym w teologii, tym bardziej że zawierały odniesienia do brewiarza, odmawianego wtedy jeszcze w języku Wulgaty33. Natomiast dla gości i turystów przeznaczona była tablica obrazująca dzieje świątyni. Całość przekazu ujętego w dekoracji drzwi i towarzyszących im elementów wystroju kruchty miała prowadzić do głębszej refleksji, a także ukazywać obraz Opieki Bożej roztaczanej nad tym miejscem mimo przeciwności losu ${ }^{34}$. Zapewne nie bez znaczenia dla szczególnie wyszukanej formy przekazu ideowego drzwi do kruchty w katedrze poznańskiej, dziś zapomnianych, ma fakt, że umiejscowienie ich w planie budowli jest analogiczne do słynnej gnieźnieńskiej Porta Regia, przez którą również prowadziła droga z pałacu biskupiego do wnętrza katedry.

31 Pozostałe prace wykonano także w warsztacie Daczki w Rydzynie.

32 Informacja uzyskana w 2010 r. od ks. Mariana Lewandowskiego, ówczesnego dyrektora Muzeum Archidiecezjalnego w Poznaniu.

33 Sobór Watykański II wprowadził nowe oficjum konstytucją apostolską „Laudis canticum" z 1 XI 1970. Tekst został wydany dopiero w latach 1970-1971 z zaleceniem tłumaczenia na języki narodowe. Polski przekład został zatwierdzony przez Kongregację ds. Kultu Bożego 15 II 1977 r. i ogłoszony dekretem Prymasa Stefana Wyszyńskiego 2 II 1978 r. (W. Głowa, Liturgia Godzin, (w:) Encyklopedia Katolicka, t. X, Lublin 2004, s. 1207).

${ }^{34}$ Po uruchomieniu w następnych latach innego wejścia do katedry od strony pałacu biskupiego, znaczenie kruchty zmalało, jej wystrój stopniowo został zdekompletowany, a obecnie wnętrze to sprawia wrażenie nieco zaniedbanego i zapomnianego (pozostały tylko drzwi i płaskorzeźba nad nimi). 
W świetle zachowanych fragmentarycznych informacji, można przypuszczać, że dekoracja tych właśnie drzwi stanowi także pewien materialny ślad, drobny refleks asocjacji wywołanych formą Drzwi Gnieźnieńskich i publikacją wyników badań nad tym arcydziełem sztuki średniowiecznej, prowadzonych szczególnie intensywnie w pierwszych latach po wojnie i zebranych w monumentalnym opracowaniu wydanym pod redakcją Michała Walickiego w latach 1956-195935.

W tym kontekście trudno nie zwrócić uwagi na podobieństwa powojennych dziejów kościołów katedralnych w Poznaniu i Gnieźnie. Do marca 1946 roku arcybiskupstwa gnieźnieńskie i poznańskie związane były unią personalną. Obie budowle zostały zniszczone i spalone w 1945 ro$\mathrm{ku}^{36}$. W obu po wojnie prowadzono na szeroką skalę prace wykopaliskowe w związku z badaniami nad początkami państwa polskiego i obie zostały zregotycyzowane według zbliżonego zamysłu. Nic dziwnego, że duchowieństwo obu diecezji, postawione wobec podobnych problemów, ściśle współpracowało ze sobą, dzieląc się wzajemnie doświadczeniami z placu robót, a jednocześnie ze sobą rywalizowało ${ }^{37}$. Księży kierowano na studia z zakresu historii sztuki i konserwacji zabytków, aby mogli profesjonalnie kierować pracami przy renowacji zniszczonych obiektów. Finansowana przez państwo odbudowa była skorelowana z badaniami naukowymi, w których nacisk kładziony był na dzieje wczesnopiastowskie. $\mathrm{O}$ randze przedsięwzięcia świadczy fakt, że były one prowadzone - zarówno w Poznaniu, jak i w Gnieźnie - pod auspicjami Polskiej Akademii Nauk.

Od 1954 roku Stacją Zakładu Archeologii Polski Poznań-Katedra kierował Zdzisław Kępiński, profesor Uniwersytetu Poznańskiego ${ }^{38}$. Jednocześnie $\mathrm{w}$ kręgu jego zainteresowań badawczych pozostawały wtedy zagadnienia związane z ikonografią Drzwi Gnieźnieńskich, których efek-

\footnotetext{
${ }_{35}$ Drzwi Gnieźnieńskie, red. M. Walicki, t. I, Wrocław 1956, t. II-III Zakład, Wrocław 1959.

36 Katedra poznańska została spalona w czasie działań wojennych, a dzieła zniszczenia dokonała armia radziecka już po wyzwoleniu (B. Korzeniowski, Sława $i$ infamia, Warszawa 1988, s. 118). Katedra gnieźnieńska została spalona przez Sowietów w kilka dni po zajęciu miasta (W. Śmielecki, B. Bielecki i M. Szczepaniak, Spalenie katedry gnieźnieńskiej, Gniezno 2015).

${ }_{37} \mathrm{Na}$ podst. informacji prof. T. Żuchowskiego. Między ks. Tomaszkiewiczem i ks. Dzierwą z pewnością nie było jednak rywalizacji; jak twierdzą wiarygodni świadkowie, łączyła ich autentyczna przyjaźń.

38 Zdzisław Kępiński (1911-1978) w latach 1949-1951 był zastępcą dyrektora Naczelnej Dyrekcji Muzeów i Ochrony Zabytków przy Ministerstwie Kultury i Sztuki w Warszawie i należał do Kierownictwa Badań nad Początkami Państwa Polskiego, koordynującego ogólnopolskie milenijne prace badawcze (A. Łosińska, Poznańska archeologia „PAN-owska”, Instytut Archeologii i Etnologii PAN, http://www.iaepan.poznan.pl/index. php?option=com_content\&task=view\&id=2\&Itemid=23 z 9 XII 2013.
} 
tem miała być publikacja wydana kilka lat później we wspomnianej już zbiorowej monografii ${ }^{39}$. W artykule Symbolika Drzwi Gnieźnieńskich Kępiński jako pierwszy z badaczy wskazuje na szczególne znaczenie bordiury i związek zdobiących ją przedstawień w zestawieniu z odpowiednimi - sąsiednimi kwaterami figuralnymi. Kępiński zwraca uwagę, że w dziele twórców średniowiecznych „sceny głównej narracji i rama bordiury zróżnicowane są także $\mathrm{w}$ ten sposób, że na polach (...) dominują monumentalne figury ludzkie (...), podczas gdy w bordiurze dominantę wzrokową stanowi dekoracyjna wić roślinna”, w którą wpleciono rozmaite wyobrażenia. Następnie w erudycyjnym wywodzie poddaje analizie każde $\mathrm{z}$ przedstawień wpisanych $\mathrm{w}$ ornament bordiury, aby dojść ostatecznie do wniosku, że zawiera ona „refleksyjny komentarz” do głównych scen ukazanych na drzwiach ${ }^{40}$. „Propozycja Kępińskiego, przypominająca w niektórych momentach koncepcję ikonologiczną Erwina Panofsky'ego, uwzględniała zależności kompozycyjne, formalne. Należy też pamiętać, że pod koniec lat 50. ikonologia jako metodologia historii sztuki była stosunkowo słabo znana, a badacze polscy, jak m.in. Lech Kalinowski byli pierwszymi, którzy ją stosowali”.

„W środowisku poznańskim profesor Kępiński był postacią wyjątkową, a jego prace - ze względu na retoryczną skuteczność - dobrze znane i dyskutowane"41. Ks. Dzierwa jako erudyta, zafascynowany historią i dziełami sztuki związanymi ze św. Wojciechem, przede wszystkim Drzwiami Gnieźnieńskimi, z pewnością znał artykuł Kępińskiego, podobnie jak ks. Tomaszkiewicz, członek poznańskiego oddziału Stowarzyszenia Historyków Sztuki. Niewątpliwie więc w tworzeniu programu ikonograficznego drzwi do kruchty katedry poznańskiej zainspirowali się także artykułem profesora. Inspiracja tym tekstem polegała nie na naśladowaniu techniki przedstawień występujących na drzwiach, jak w przypadku białych witraży w Coventry, ale na tym, iż nadano bordiurze znaczenie wykraczające poza zazwyczaj stosowane dekoracyjne opracowanie obramienia głównej sceny. Program emblematyczno-słowny na poszczególnych listwach zawiera nie tylko komentarz nawiązujący do symboliki przedstawionych na płycinach archaniołów, ale przede wszystkim zawiera przekaz rozbudowujący wymowę głównej sceny. Można przypuszczać, że nieprzypadkowo w ślad za interpretacją Kępińskiego autorzy programu ikonografii drzwi do kruchty poznańskiej właściwie skoncentrowali się przede wszystkim na metalowej ramie, tam zamieszczając wyczer-

39 Z. Kępiński, Symbolika Drzwi Gnieźnieńskich, op. cit., s. 161-290.

${ }^{40}$ Ibidem, s. 162, 283.

${ }^{41}$ Komentarz profesora T. Żuchowskiego w korespondencji z autorką niniejszego artykułu z 17 marca 2015 r. 
pujący komentarz do statycznych dostojnych postaci anielskich wprowadzających widza do wnętrza świątyni.

Wobec narzucającej się analogii trudno nie pokusić się też o porównanie sposobu myślenia symbolicznego twórcy średniowiecznego i współczesnego, zachowując świadomość różnic w znaczeniu i randze zamówienia. Autor programu ikonograficznego drzwi średniowiecznych reprezentował typową dla swoich czasów postawę, według której omnis natura Deum loquitur, i wyrażał ją za pomocą przedstawień figuralnych, kryjących całe bogactwo związków i znaczeń. Natomiast współcześni twórcy drzwi poznańskich preferują znaki w postaci liter, anagramów i słów, dopełnionych obrazami zakorzenionymi w tradycji i unikają złożonych narracji. Erudycyjną wiedzę czerpaną zapewne z ksiąg zgromadzonych w benedyktyńskiej bibliotece zakonnej zastąpiła nauka i sposób myślenia symbolicznego oparty na informacjach wyniesionych z zajęć paleografii, prowadzonych na XX-wiecznym uniwersytecie. Kontynuując analogię można też stwierdzić, że twórca przedstawień bordiury gnieźnieńskiej opracowywał je z pieczołowitą powagą i kunsztem, zaś młody artysta współczesny raczej bawił się formą, kierując się inwencją i nastrojem chwili.

W ostatnim półwieczu powstało wiele rzeźbionych drzwi kościelnych, najczęściej odlewanych $\mathrm{w}$ brązie, czasem repusowanych $\mathrm{w}$ blasze miedzianej, rzadziej - trawionych. Ujęte na nich przedstawienia zawierają często bogate wielowątkowe treści, ale $\mathrm{w}$ żadnych bordiura nie odgrywa tak wielkiego znaczenia jak na niepozornych drzwiach do kruchty południowej katedry poznańskiej. Wymienione powyżej przesłanki pozwalają przypuszczać, że bogactwo zawartych w niej treści to owoc inspiracji tekstem naukowej interpretacji dekoracji arcydzieła sztuki średniowiecznej.

\section{INTERPRETATION AS INSPIRATION? DECORATION OF THE PORCH OF THE POZNAŃ CATHEDRAL}

Summary

In the southern porch of the Poznan cathedral there is a swinging door etched in bronze and brass, made in 1972. Together with a bronze bas-relief placed above, it was the most important element of the decoration of the passage from the residence of Poznan archbishops to the cathedral. Both artworks were made by Ireneusz Daczko and Bogdan Fijałkowski - graduates of the Poznań Academy of Fine Arts. Their project was inspired by Rev. Stefan Tomaszkiewicz, who supervised construction work in the cathedral, and Rev. Bolesław Dzierwa, involved in the restoration of the cathedral in Gniezno. Both priests developed an original iconographic program of 
the porch decoration, based upon angelistic, christological, and mariological symbolism and texts in Polish, Latin, and Greek.

The figures of archangels Gabriel and Michael in the door panels have a border with inscriptions, monograms, angels, and zoomorphic motifs, and objects intertwined with climbing plants. The decoration of the door and the bas relief showing the Assumption of Mary includes many references to the liturgy of the breviary, and points to the clergy as the recipients of the ideas represented in the porch iconography.

The main argument of the paper is that the iconography of the Poznan door derives from the texts by Lech Kalinowski and, above all, Zdzisław Kępiński, who in his article, "The Symbolism of the Gniezno Door," was the first to emphasize the significance of the border and the connection of its decoration with the correspondent figural panels of the bronze Gniezno door. 